\title{
ANALISIS PENGARUH INFLASI DAN PERTUMBUHAN EKONOMI TERHADAP PENGANGGURAN
}

\author{
Oleh: Delima Sari Lubis \\ Dosen Jurusan Ekonomi Syariah Fakultas Ekonomi dan Bisnis Islam \\ IAIN Padangsidimpuan \\ Email: delimasarilubis@gmail.com
}

\begin{abstract}
One of the problems being going developing countries is unemployment. Unemployment is a quite complicated problem and requires seriousness in solving it. If economic growth increases it will cause unemployment to decline. The result of research shows that partially variable of inflation does not have significant effect to unemployment.It is based by $t_{\text {count }}\left(-0.147921<t_{\text {table }}(2.01537\right.$. While the economic growth variable has no effect on unemployment. The t test shows the obtained $t_{\text {count }}(-0.369640)<t_{\text {table }}$ (2.01537). Simultaneously, the variables of inflation, economic growth and dummy variables have an effect on unemployment cause $F_{\text {count }}(7.101933)>F_{\text {table }}(2.82)$. The determination coefficient test is 0.509637, It indicates that the independent variables are able to explain the dependent variable of 50.9 percent, while the 49.1 percent is influenced by other variables outside of this research. The research equation that is $P G=$ $17.43638+(-0.014508 * I N F)-(0.240327 * P E)+(-5.072613 * D U M M Y)+e_{i t}$.
\end{abstract}

Keywords: Inflation, Economic Growth and Unemployment

\section{A. Latar Belakang Masalah}

Indonesia merupakan salah satu negara berkembang. Salah satu permasalahan yang sedang dihadapi oleh negara berkembang adalah pengangguran. ${ }^{1}$ Pengangguran merupakan suatu keadaan dimana seorang angkatan kerja tidak memiliki pekerjaan dan secara aktif sedang mencari kerja tetapi belum dapat memperolehnya. ${ }^{2}$ Hal ini disebabkan oleh keterbatasan lapangan pekerja yang tersedia, sehinggatidak dapat menampung sejumlah angkatan kerja. Dalam rangka pembangunan ekonomi di negara-negara berkembang, pengangguran merupakan masalah yang cukup rumit dan 
membutuhkan keseriusan dalam menyelesaikannya. Oleh karena itu, masalah pengangguran yang dihadapi dari tahun ketahun semakin meningkat.

Salah satu provinsi di Indonesia yang menghadapi sejumlah masalah terkait dengan pengangguran adalah Sumatera Utara. Adapun daerah yang menjadi objek dalam penelitian ini adalah kota Medan, Kota Pematang Siantar, Kota Sibolga, dan Kota Padangsidimpuan. Rata-rata angka pengangguran di Kota Medan selama 2004 sampai 2015 sebesar 151,34 \%. Sedangkan pada kota Pematangsiantar jumlah rata-rata pengangguran pada rentang tahun sama sebesar $135,06 \%$. Untuk kota Padangsidimpuan rata-rata pengangguran sedikit lebih rendah, yaitu sebesar 133,69 \%. Selanjutnya Kota Sibolga rata-rata pengangguran justru lebih tinggi dari kota lain, yaitu sebesar 181,77\%.

Tingkat pengangguran di empat kotatersebut relatif tinggi, hal ini disebabkan karena daerah perkotaan menghadapi arus urbanisasi (migrasi), sehingga pertambahan jumlah penduduk terjadi dengan cepat sementara itu, ketersediaan lapangan pekerjaan tidak mencukupi. Penduduk yang sedang mencari pekerjaan ini dapat disebut pengangguran terbuka atau pengangguran penuh. Pengangguran initercipta sebagai akibat pertambahan lowongan pekerjaan yang lebih rendah dari pertambahan jumlah tenaga kerja. Hal tersebut akan berdampak pada banyak jumlah tenaga kerja yang tidak dapat memperoleh pekerjaan. Untuk jangka panjang, kondisi ini akan berdampak terhadap laju inflasi.

Inflasi merupakan suatu keadaan meningkatnya harga-harga barang secara umum dan berlangsung secara terus menerus pada suatu periode tertentu. ${ }^{3}$ Indikator yang sering digunakan untuk mengukur tingkat inflasi adalah Indeks Harga Konsumen (IHK). Perubahan IHK dariwaktu ke waktu menunjukkanpergerakan harga dari paket barang dan jasa yang dikonsumsi masyarakat.Kestabilan inflasi merupakan prasyarat bagi pertumbuhan ekonomi suatu daerah atau negara.

Inflasi tertinggi terjadi pada tahun 2005 dan berfluktuasi di tahun-tahun berikutnya. Sedangkan inflasi terendah terjadi pada tahun 2009. Berdasarkan hasil penelitian A. W. Phillips tentang perekonomian Inggris periode 1861-1957, menunjukkan adanya hubungan negatif dan non linear antara kenaikan tingkat 
upah atau inflasi tingkat upah dengan pengangguran. ${ }^{4}$ Selain inflasi, tingkat pertumbuhan ekonomi juga merupakan faktor yang mempengaruhi pengangguran.

Indikator dari pertumbuhan ekonomi yang digunakan adalah Produk Domestik Ragional Bruto (PDRB). PDRBmerupakan indikator penting untuk mengetahui kondisi ekonomi disuatu daerah dalam suatu periode tertentu, baik atas dasar harga berlakumaupun atas dasar harga konstan. PDRB pada dasarnya merupakan jumlah nilai tambah yang dihasilkan oleh seluruh unit usaha dalam suatu daerah tertentu, atau merupakan jumlah nilai barang dan jasa akhir yang dihasilkan oleh seluruh unit ekonomi pada suatu daerah. Laju pertumbuhan ekonomi tertinggi terjadi di kota Medan dengan persentase rata-rata sebesar $81.48 \%$, kemudian Padangsidimpuan sebesar $67.37 \%$ dan Sibolga sebesar 65.08 $\%$, sedangkan Pematangsiantar hanya sebesar $63.01 \%$. Berikut lebih jelas grafik laju pertumbuhan ekonomi

\section{Grafik 1}

Laju Pertumbuhan Ekonomi Kota Medan, Pematangsiantar, Padangsidimpuan, dan Sibolgatahun 2004-2015 (\%)

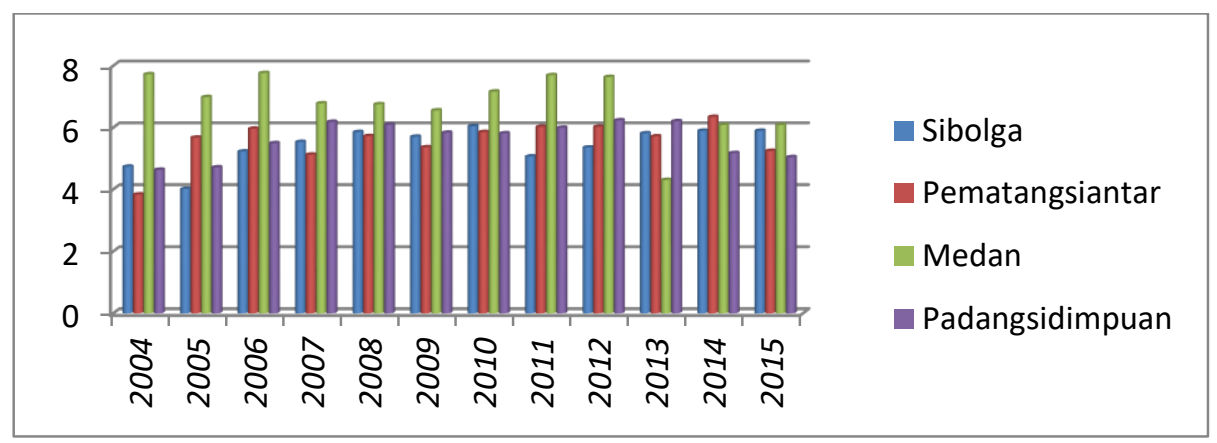

Sumber: BPS Sumatera Utara, diolah

Adapun pola hubungan antara pengangguran dan pertumbuhan ekonomi, menyebutkan bahwa pengangguran yang tinggi akan diikuti oleh penurunan laju pertumbuhan ekonomi. Sedangkan laju pertumbuhan ekonomi yang tinggi akan diikuti oleh meningkatnya angka pengangguran dan laju pertumbuhan ekonomi rendah akan menyebabkan pengangguran yang menurun. ${ }^{5}$ Berdasarkan uraian di atas maka peneliti tertarik untuk melakukan penelitian dengan judul "Analisis Pengaruh Inflasi dan Pertumbuhan Ekonomi Terhadap Pengangguran" 


\section{B. Rumusan Masalah}

Berdasarkan latar belakang masalah, maka rumusan masalah penelitian ini adalah"Apakah inflasi dan pertumbuhan ekonomi memiliki berpengaruh terhadap pengangguran baik secara parsial maupun secara simultan?

\section{LandasanTeori}

\section{Pengangguran}

Pengangguran merupakan masalah makroekonomi yang mempengaruhi manusia secara langsung. Bagi kebanyakan orang, kehilangan pekerjaan berarti penurunan standar kehidupan. Jadi tidak mengejutkan jika pengangguran menjadi topik yang sering dibicarakan dalam berbagai perdebatan politik dan para politisi atau pemimpin sering mengklaim bahwa kebijakan yang ditawarkan akan membantu mengurani pengangguran. Menurut Sukirno, pengangguran adalah jumlah tenaga kerja dalam perekonomian yang secara aktif mencari pekerjaan tetapi belum memperolehnya. ${ }^{6}$ Pengangguran menurut Samuelson merupakan masalah sosial yang besar karena mengakibatkan penderitaan besar untuk pekerja yang menganggur yang harus berjuang dengan pendapatan yang berkurang. Jika pengangguran tinggi, keadaan ekonomi yang sulit meluap dan mempengaruhi emosi masyarakat dan kehidupan keluarga

Pengangguran dalam sudut pandang Islam, telah digambarkan Allah dalam surat Huud ayat 6, yang menjelaskan bahwa semua makhluk yang ada di atas bumi ini sudah dijamin Allah rezekinya. Hanya saja makhluk tersebut dituntut untuk bergerak mencari rezeki tersebut. Makhluk dalam hal ini mencakup manusia dan binatang. Artinya agar setiap diri tidak tinggal diam menanti rezeki yang sudah digariskan Allah, akan tetapi agar terus bergerak dan berusaha memperoleh rezeki tersebut.

\section{Inflasi}

Inflasi dianggap sebagai sebuah fenomena moneter, karena terjadi penurunan nilai unit penghitungan moneter terhadap suatu komunitas. Inflasi merupakan gejala yang menunjukkan adanya kenaikan tingkat harga secara umum yang berlangsung terus-menerus atau suatu keadaan yang ditimbulkan 
oleh tidak adanya keseimbangan antara permintaan akan barang-barang dan persediaannya. $^{7}$

Terdapat beberapa indikator ekonomi makro yang digunakan untuk mengetahui laju inflasi selama satu periode tertentu yaitu: ${ }^{8}$ Pertama, Indeks harga konsumen (IHK). IHK adalah angka indeks yang menunjukkan tingkat harga barang dan jasa yang harus dibeli konsumen dalam suatu periode tertentu.Dalam IHK, setiapjenis barang ditentukansuatu timbangan atau bobot tetap yang profesional terhadap kepentingan relatif dalam anggaran pengeluaran konsumen.Kedua, Indeks harga perdagangan besar (IHPB). IHPBmenunjukkan tingkat harga yang diterima produsen pada berbagai tingkat produksi.Ketiga, Indeks harga implisit, adalah suatu indeks yang merupakan perbandingan atau rasio antara GNP nominal dan GNP riil dikalikan dengan 100. GNP riil adalahnilai barang-barang dan jasa-jasa yang dilakuakn didalam perekonomian, yang diperoleh ketika output dinilai dengan menggunakan harga tahun dasar.

Hubungan antara tingkat inflasi dan tingkat pengangguran telah diamai oleh A.W Philips berdasarkan depresi ekonomi yang terjadi di Amerika Serikat tahun 1992. Dari hasil pengamatannya, ternyata ada hubungan yang erat antara inflasi dengan tingkat pengangguran, dalam arti jika inflasi tinggi, maka pengangguran akan rendah. Kurva Phillips adalah kurva yang menggambarkan hubungan antara negatif dan antara inflasi dan pengangguran.Semakin tinggi tingkat inflasi, maka tingkat pengangguran semakin tinggi.A.W Phillips menggambarkan bagaimana sebaran hubungan antara inflasi dengan tingkat pengangguran didasarkan pada asumsi bahwa inflasi merupakan cerminan dari adanya kenaikan permintaan agregat.Dengan naiknya permintaan agregat, maka harga-harga akan naik. Sesuai dengan teori permintaan. Jika permintaan naik, maka harga akan naik. Dengan tingginya harga, maka untuk memenuhi permintaan tersebut produsen meningkatkan kapasitas produksinya dengan menambah tenaga kerja dengan asumsi, tenaga kerja merupakan satu-satunya faktor yang dapat meningkatkan produksi.Akibat dari peningkatan permintaan tenaga kerja maka pengangguran berkurang. 


\section{Pertumbuhan Ekonomi}

Pertumbuhan ekonomi merupakan salah satu indikator yang sangat penting dalam menilai kinerja perekonomian, terutama untuk melakukan analisis tentang hasil pembangunan ekonomi yang telah dilaksanaan suatu negara atau suatu derah.Dengan demikian, pertumbuhan ekonomi menujukkan sejauh mana aktifitas perekonomian dapat menghasilkan tambahan pendapatan atau kesejahteraan masyarakat pada periode tertentu.Pendapat Smith pertumbuhan ekonomi mengatakan bahwa apabila pembangunan sudah terjadi, maka proses tersebut akan terus menerus berlangsung secara komulatif. Kenaikan pendapatan nasional yang disebabkan oleh perkembangan tersebut dan perkembangan penduduk, akan memperluas pasar dan menciptakan tabungan yang lebih besar.

Alat pengukur pertumbuhan perekonomian ada beberapa macam diantaranya:pertama, Produk Domestik Bruto (PDB), merupakan jumlah barang dan jasa akhirnya yang dihasilkan oleh suatu perekonomian dalam suatu tahun dan dinyatakan dalam harga pasar.Kedua, Produk Domestik Bruto Per Kapita (Pendapatan per Kapita), yaitu jumlah PDB nasional dibagi dengan jumlah penduduk atau disebut sebagai PDB rata-rata atau PDB per kapita.Ketiga, Pendapatan per jam kerja merupakan upah atau pendapatan yang dihasilakan perjamkerja. Biasanya suatu negara yang mempunyai tingkat pendapatan atau upah per jam kerja lebih tinggi dari pada di negara lain, boleh dikatakan negara yang bersangkutan lebih maju dari pada negara yang satunya. ${ }^{9}$

Adapun hubungan antara pertumbuhan ekonomi dan pengangguran adalah masalah utama dan mendasar dalam ketenagakerjaan di Indonesia adalah masalahupah yang rendah dan tingkat pengangguran yang tinggi.Hal tersebut disebabkan karena, pertambahan tenaga kerja baru jauh lebih besar dibandingkan dengan pertumbuhan lapangan kerja yang dapat sediakan setiap tahunnya.Pertumbuhan tenaga kerja yang lebih besar dibandingkan dengan persedian lapangan kerja menimbulkan pengangguran yang tinggi.Pengangguran merupakan salah satu masalah utama dalamjangka 
pendek yang selalu dihadapi setiap negara.Karena itu, setiap perekonomian dan negara pasti menghadapi masalah pengangguran. ${ }^{10}$

Pertumbuhan ekonomidalam Islam diindikasikan dengan upaya untuk meningkatkan kesejahteraan masyarakat dan individu dalam jangka panjang, untuk mewujudkan pertumbuhan ekonomi bagi masyarakat, tujuan fasilitas yang digunakan harus sesuai dengan nilai dan prinsip syariah yang berlandaskan Alquran dan Sunnah.Konsep pertumbuhan ekonomi konvensional tidak dinafikasikan selama tidak bertentangan prinsip syariah.Konsep pertumbuhan ekonomi telah digunakan dalam Alquran dan surat $A l-A$ 'raaf ayat 90. Ayat tersebut juga dipahami sebagai mengisyaratkan salah satu sunnah Allah yang lain yaitu bahwa Allah akan melipahkan aneka anungrah dan keberkatan kepada penduduk negri yang beriman dan bertaqwa. Sejarah islam menunjukan bahwa penduduk mekah yang durhaka kepada Allah swt, mengalami masa-masa sulit bahkan penceklik selama tujuh tahun, sedang penduduk Madinah hidup aman dan sejahtera di bawah bimbingan Rasul Saw. ${ }^{11}$

\section{Hipotesis}

$\mathrm{H}_{0}$ : Tidak terdapat pengaruh antara inflasi dan pertumbuhan ekonomi terhadap pengangguran baik secara parsial maupun secara simultan.

$\mathrm{H}_{\mathrm{a} 3}$ : Terdapat pengaruh antara inflasi dan pertumbuhan ekonomi terhadap pengangguran baik secara parsial maupun secara simultan.

\section{E. Metode Penelitian}

\section{Jenis dan Sumber Data}

Jenis data yang digunakan adalah data panel yaitu gabungan antara data time series dan data cross sectional. Data time series yang digunakan adalah data inflasi, pertumbuhan ekonomi serta pengangguran secara tahunanSedangkan data cross sectional berupa data penelitian diperoleh dari Kota Medan, Pematangsiantar, Padangsidimpuan dan Sibolga. Data yang digunakan dalam penelitian 
adalah sekunder yang telah dipublikasi oleh Badan Pusat Statistik (BPS) Provinsi Sumatera Utara.

\section{Populai dan Sampel}

Populasi penelitian ini berupa data inflasi, pertumbuhan ekonomi dan pengangguran di Provinsi Sumatera Utara, dari tahun 2000 sampai 2017 Sumatera Utara. Sedangkansampel penelitian adalah sebanyak 48 sampel, yaitu data tahunan dari tahun 2004 hingga 2015 pada empat kota sebagaimana disebutkan di atas.Maka, total sampel dalam penelitian ini berjumlah 48 sampel.

\section{Analisa Data}

Analisa data penelitian dilakukan dengan bantuan Eviews versi 9.0. Sebelum melakukan analisis data maka dilakukan uji normalitas sebagai prasyarat analisa parametrik dan uji asumsi klasik untuk prasyarat regresi berganda. Adapun jenis uji asumsi klasik yang dilakukan terdiri dari uji multikolineritas, Autokerelasi, dan Heterokedastisitas.

Beberapa metode analisa data yang digunakan untuk data panel adalah; Model Pooled Least square (Common Effect), Model pendekatan efek tetap (fixed effect), dan Model pendekatan efek acak (Random Effect). ${ }^{12}$ Sedangkan mekanisme uji pada data panel untuk menentukan metode pemilihan yang tepatdilakukan dengan cara membandingkan metode pelaksanan (Pooled Least Square) PLS dengan metode pendekatan (Fixed Effect Model) FEM terlebih dahulu. Untuk melakukan model mana yang akan dipakai maka dilakukan pengujian diantaranya; uji chow test danuji hausman test

Analisis regresi berganda digunakan untuk memprediksi nilai suatu variabel dependen berdasarkan dua atau lebih variabel independen. Persamaan penelitian; PG $=\beta_{0^{-}} \beta_{1} \mathrm{INF}_{1 \mathrm{it}}+\beta_{2} \mathrm{PE}_{2 \mathrm{it}}+\beta_{3}$ Krisis 3 it $+\mathrm{e}_{\mathrm{it} . .}$ Kemudian dilakukan uji hipotesis; yang terdiri dari $\mathrm{R}^{2}$, uji t dan Uji F. 


\section{F. Hasil Penelitian}

\section{Uji Normalitas dan Asumsi Klasik}

Untuk uji normalitas dihitung dengan uji Jargu-Beara (JB), apabila $\mathrm{JB}_{\text {hitung }}<$ nilai $\mathrm{X}_{2}$ (chi-square) $)_{\text {table, }}$ maka data berdistribusi normal dan $\mathrm{JB}_{\text {hitung }}>$

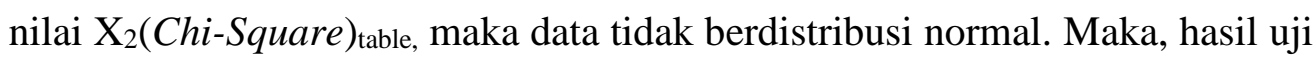
ini diketahui nilai $\mathrm{JB}_{\text {hitung }}$ sebesar 8.943774 dan nilai chi square dengan derajat kebebasan 3 alpha 5\% sebesar 7.82 sehingga dapat disimpulkan nilai $\mathrm{JB}_{\text {hitung }}$ berdistribusi normal.

Untuk uji multikolinearitas dapat dideteksi dengan melihat matrik korelasi antara variabel dependen. Jika inflasi, pertumbuhan ekonomi dan dummyterdapat kolerasi yang kuat di atas 0.8 maka dapat disimpulkan terdapat multikolinearitas.Berdasarkan tabel diberikut nilai yang terdapat tidak ada diatas 0.8 maka dapat disimpulkan data tidak terjadi multikolinearitas.

Tabel 1

Uji Multikolinearilitas

\begin{tabular}{|c|c|c|c|}
\hline & INF & PE & DUMMY \\
\hline INF & 1 & -0.1615026497504909 & -0.3898842600679335 \\
\hline PE & -0.1615026497504909 & 1 & 0.1505707154257184 \\
\hline DUMMY & -0.3898842600679335 & 0.1505707154257184 & 1 \\
\hline
\end{tabular}

Sedangkan untuk mendeteksi terjadi atau tidaknya heteroskedastisitas dilakukan dengan menggunakan uji Park, dengan ketentuan apabila nilai probability variabel independen di atas nilai taraf signifikan maka data dapat disimpulkan tidak terjadi masalah heterokedastisitas. Berikut ini hasil uji Park yang dilakukan terhadap data yang digunakan dalam penelitian ini : 
Tabel 2

Uji Heteroskedastisitas

\begin{tabular}{|c|r|r|r|r|}
\hline Variable & Coefficient & Std. Error & t-Statistic & Prob. \\
\hline \multicolumn{5}{|c|}{} \\
\hline C & -5.053957 & 18.87889 & -0.267704 & 0.7903 \\
\hline INF & -0.257045 & 0.461954 & -0.556431 & 0.5809 \\
\hline PE & 2.197290 & 3.062261 & 0.717538 & 0.4771 \\
\hline DUMMY & 3.431425 & 4.846616 & 0.708004 & 0.4829 \\
\hline \multicolumn{5}{|c}{ Effects Specification } \\
\hline \multicolumn{6}{|c|}{ Cross-section fixed (dummy variables) } \\
\hline \multicolumn{6}{|c|}{} \\
\hline
\end{tabular}

Berdasarkan tabel di atas, dapat dilihat bahwa nilai probability untuk semua variabel independen berada di atas 0,05 dengan rincian probability inflasi sebesar0,5809, pertumbuhan ekonomi sebesar 0,4771, dan dummy sebesar 0,4829. Dengan demikian maka dapat disimpulkan bahwa tidak ditemukan adanya masalah heteroskedastisitas pada penelitian.

Untuk uji autokorelasi, dapat dilihat pada tabel 2 di atas, dimana nilai D-Wpada output sebesar 2.22, dengan demikian tidak terdapat autokorelasi dikarenakan D-W berada diantara 1.54 hingga 2.46.

\section{Pemilihan Model Estimasi Data Panel}

Dalam model regresi menggunakan data panel, langkah pertama yang dilakukan adalah memilih model estimasi yang tepat. Regresi data panel memiliki tiga model. Pertama,Common Effect Model (Pooled Least Square) dengan metode OLS (Ordinar Lleast Square).Kedua, Fixed Effect Model dengan menambah variabel dummy pada data panel. Ketiga, Rondom Effect Model dengan menghitungerrordari data panel menggunakan OLS (Ordinary Least Square). Ketiga model diatas selanjutnya diuji satu per satu.

Setelah melakukan uji estimasi, selanjutnya dipilih model estimasi yang tepat. Pemilihan model estimasi yang tepat dilakukan dengan menggunakan dua uji lain, yaitu uji chow (likelihood ratio), hausman test.Adapun dasar pengambilan keputusan adalah dengan membandingkan nilai chi-square hitung dengan chi-square tabel.Dasar penolakan terhadap hipotesis di atas adalah dengan membandingkan perhitungan $\chi^{2}$ hitung dengan 


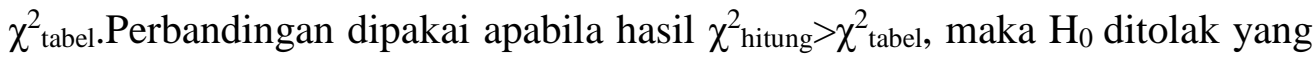
berarti model yang lebih tepat digunakan adalah FixedEffect.Begitupun sebaliknya, jika $\chi^{2}$ hitung $<\mathrm{d} \chi^{2}$ tabel, maka $\mathrm{H}_{\mathrm{a}}$ diterima dan model yang digunakan adalah Common Effect. Berikut adalah hasil uji Chow yang dilakukan dalam penelitian ini:

Tabel 3

Uji Chow

\begin{tabular}{|l|c|c|c|}
\hline \multicolumn{4}{|c|}{ Test cross-section fixed effects } \\
\hline Effects Test & Statistic & Df & Prob \\
\hline Cross-section F & 2.931230 & $(3,42)$ & 0.0444 \\
\hline Cross-section Chi-square & 9.124920 & 3 & 0.0277 \\
\hline
\end{tabular}

Berdasarkantabel di atas, diketahui bahwa nilai chi-square yang diperoleh adalah $9.124920>$ chi square tabel 7.81473 sehingga dapat disimpulkan bahwa $\mathrm{H}_{\mathrm{o}}$ ditolak dan $\mathrm{H}_{\mathrm{a}}$ diterima. Hasil dari uji ini menyatakan bahwa model yang paling sesuai antara comman effectdan fixed effectadalah fixed effect.

Uji selanjutnya dalam menentukan model estimasi terbaik adalah hausman testdalam uji hausman, model yang akan dibandingkan adalah random dan fixed effect.Uji hausmanini mengikuti distribusi statistik $\chi^{2}$ (ChiSquare) dengan degree of freedom (d.f.) sebanyak k, dimana k adalah jumlah variabel independen. Jika nilai statistik hausmanlebih besar dari nilai kritisnya, maka $\mathrm{H}_{0}$ ditolak dan model yang lebih tepat adalah model fixed effect sedangkan sebaliknya bila nilai statistik hausmanlebih kecil dari nilai kritisnya, maka model yang lebih tepat adalah model random effect. Hasil uji hausmandapat dilihat pada tabel berikut.

Tabel 4

\section{Hasil Uji Hausman}

\begin{tabular}{|l|l|l|l|}
\hline \multicolumn{4}{|l|}{ Correlation Random Effects - Hausman Test } \\
\hline Test Cross-section random Effects \\
\hline Test Summary & Chis-Sq statistic & Chi-Sq d f & Prob \\
\hline Cross-section random & 8.427709 & 2 & 0.0148 \\
\hline
\end{tabular}


Nilai Chi-Square hitung pada tabel diatas adalah sebesar $8.427709>$ chisquare $_{\text {tabel }} 5.99146$ dengan demikian, $\mathrm{H}_{\mathrm{o}}$ diterima dan model yang paling sesuai menurut uji hausmanadalah fixed effect. Maka, berdasarkan kedua uji yang telah dilakukan dapat disimpulkan bahwa model yang akan digunakan adalah fixed effect model. Fixed effect modeladalah model estimasi yang memiliki intersep yang berada pada setiap cross sectionnya. Selain itu, model ini juga menggunakan variabel dummy sebagai variabel bebas. Variabel dummy dalam penelitian ini adalah krisis ekonomi yang terjadi pada tahun 2008.

\section{Uji Hipotesis}

Uji t dilakukan untuk melihat pengaruh masing-masing variabel bebas terhadap variabel terikat.Nilai signifikan yang digunakan adalah 0.05. dengan derajat kebebasan 2.01537.Ketentuan yang digunakan adalah sebagai berikut:Apabila hasil $t_{\text {hitung }}>t_{t a b e l}$, maka $\mathrm{H}_{0}$ ditolak yang berarti model yang lebih tepat digunakan adalah fixedeffect.Begitupun sebaliknya, jika $\mathrm{t}_{\text {hitung }}<\mathrm{t}_{\text {tabel}}$, maka $\mathrm{H}_{0}$ diterima dan model yang digunakan adalah common effect.jadi hipotesis dalam penelitian ini menggunakan model estimasi fixed effect. Hasil uji estimasinya dapat dilihat pada tabel dibawah ini.

\section{Tabel 5}

\section{Uji t}

\begin{tabular}{|l|l|l|}
\hline Variabel & t-statistik & Prob \\
\hline C & 4.350101 & 0000 \\
\hline INF & -0.147921 & 0.8831 \\
\hline PE & -0.369640 & 0.7136 \\
\hline DUMMY & -4.929610 & 0.0000 \\
\hline
\end{tabular}

Berdasarkan hasil uji hipotesis diatas dapat diambil kesimpulan bahwa; Pertama, Berdasarkan uji thitung diatas, thitung yang diperoleh adalah 0.147921. Nilai ini lebih kecil dari dari tabel yang diperoleh 2.01537. Berdasarkan pengujian ini maka $\mathrm{H}_{\mathrm{o}}$ diterima dan $\mathrm{H}_{\mathrm{a}}$ ditolak.Sehingga dapat disimpulkan variabel inflasi tidak berpengaruh terhadap pengangguran.Kedua,Nilai thitung yang diperoleh dari hasil uji diatas adalah 0.369640.Nilai $\mathrm{t}$ hitung yang diperoleh ini lebih kecil dari nilai $\mathrm{t}$ tabel 
2.01537.berdasarkan pengujian ini maka $\mathrm{H}_{\mathrm{o}}$ diterima dan $\mathrm{H}_{\mathrm{a} 2}$ tolak sehingga dapat disimpulkan variabel pertumbuhan ekonomi tidak berpengaruh terhadap pengangguran Ketiga, Variabel dammy merupakan variabel boneka yang digunakan jika model estimasi terpilih adalah fixed effect. Variabel ini digunakan untuk melihat pengaruh krisis ekonomi pada tahun 2008 terhadap pengangguran.Nilai thitungyangdiperoleh dari uji diatas sebesar -4.929610nilai ini lebih besar dari nilai tabel 2.01537.Berdasarkan pengujian ini maka variabel dammy berpengaruh terhadap pengangguran.

Hasil penelitian di empat kota pada provinsi Sumatera Utara cendrung tidak sama dengan pendapat Rozalinda yang mengatakan bahwa "ada hubungan antara inflasi dengan pengangguran"dan hasil penelitian A.W. Phillips, yang menggambarkan adahubungan negatif antara inflasi dan pengangguran. Selain itu, untuk hasil pertumbuhan ekonomi juga tidak sesuai dengan pendapat Mankiw,yang menyatakan bahwa terdapat hubungan yang negatif antara pertumbuhan ekonomi dan pengangguran.Ketika terjadi penurunan pertumbuhan ekonomi maka akan meningkat pengangguran. Apabila pertumbuhan ekonomi meningkatmaka akan menimbulkan pengangguran menurun. ${ }^{13}$

Sedangkan uji $\mathrm{F}$ digunakan untuk melihat pengaruh variabel bebas terhadap variabel terikat secara keseluruhan.Nilai $F_{\text {tabel }}$ yang diperoleh adalah 2.82 ketentuan yang digunakan adalah $\mathrm{F}_{\text {-hitung }}>\mathrm{F}_{\text {-tabel }}=\mathrm{H}_{\mathrm{O}}$ ditolak dan $\mathrm{F}_{\text {-hitung }}$ $<\mathrm{F}_{\text {-tabel }}=\mathrm{H}_{\mathrm{a}}$ diterima. Hasil uji $\mathrm{F}$ pada penelitian ini dapat dilihat pada tabel berikut :Berdasarkan tabel berikut, diperoleh nilai $\mathrm{F}$ hitung sebesar7.101933.

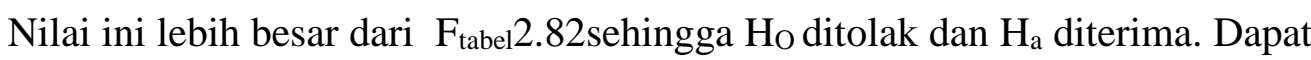
disimpulkan bahwa inflasi dan pertumbuhan ekonomi berpengaruh secara simultan terhadap pengangguran. 


\section{Tabel 6}

Uji F

\begin{tabular}{|l|l|l|l|}
\hline R-squared & 0.509637 & Mean dependent var & 12.53875 \\
\hline Adjusted R-squared & 0.437877 & S.D. dependent var & 4.096447 \\
\hline S.E. of regression & 3.071306 & Akaike info criterion & 5.216120 \\
\hline Sum squared resid & 386.7496 & Schwarz criterion & 5.489004 \\
\hline Log likelihood & -118.1869 & Hannan-Quinn criter. & 5.319243 \\
\hline F-statistic & 7.101933 & Durbin-Watson stat & 2.229294 \\
\hline Prob(F-statistic) & 0.000031 & & \\
\hline
\end{tabular}

Sementara itu, uji koefisien determinasi menunjukkan kemampuan garis regresi menerangkan variasi variabel terikat yang dapat dijelaskan oleh variabel bebas.Hasil uji koefisien determinasi dapat dilihat pada tabel 6 di atas, nilai koefisien determinasi yang diperoleh adalah0.509637. Angka tersebut menjelaskan bahwa variabel inflasi dan pertumbuhan ekonomi mampu menjelaskan variabel pengangguransebanyak 50,9persen.Sedangkan sisanya sebesar 49.1 persen dipengaruhi oleh variabel lain diluar penelitian.

Untuk analisis regresi berganda dilakukan untuk memperdiksi nilai suatu variabel dependen berdasarkan dua atau lebih variabel independen. Hasil estimasi yang diperoleh menggunakan model fixed effectdapat dilihat pada tabel berikut :

Tabel 7

Hasil Estimasi

\begin{tabular}{|l|r|l|c|}
\hline \multicolumn{4}{|c|}{ Cross-section fixed (dummy variables) } \\
\hline R-squared & 0.509637 & Mean dependent var & 12.53875 \\
\hline Adjusted R-squared & 0.437877 & S.D. dependent var & 4.096447 \\
\hline S.E. of regression & 3.071306 & Akaike info criterion & 5.216120 \\
\hline Sum squared resid & 386.7496 & Schwarz criterion & 5.489004 \\
\hline Log likelihood & -118.1869 & Hannan-Quinn criter. & 5.319243 \\
\hline F-statistic & 7.101933 & Durbin-Watson stat & 2.229294 \\
\hline Prob(F-statistic) & 0.000031 & & \\
\hline
\end{tabular}


Persamaan regresi yang digunakan dalam penelitian adalah; $\mathrm{PG}_{\mathrm{it}}=\beta_{\mathrm{o}}+$ $\beta_{1} \mathrm{INF}_{\text {it }}+\beta_{2} \mathrm{PE}_{\mathrm{it}}+\beta_{3} \mathrm{DUMMY} \mathrm{Y}_{\mathrm{it}}+\mathrm{e}_{\mathrm{it}}$. Berdasarkan persamaan tersebut, maka diperoleh model regresi $\mathrm{PG}=17.43638+(-0.014508 * \mathrm{INF})-(0.240327 * \mathrm{PE})+(-$ $5.072613 *$ DUMMY)+ $e_{i t}$ Adapun intrepretasi dari persamaan tersebut adalah;

a. Nilai intersip 17.43638memiliki arti jika inflasi dan pertumbuhan ekonomi bernilai 0,maka pengangguran sebesar 17.4 persen.

b. Nilai slope $\beta_{1}$ variabel inflasi adalah-0.014508. berdasarkan hasil ini, dapat dilihat bahwa inflasi memiliki pengaruh negatif terhadap pengangguran. Jika inflasi meningkat sebesar 1 persen, pengangguran akan menurunsebesar -0.014 persen.

c. Nilai slope $\beta_{2}$ variabel pertumbuhan ekonomi adalah - 0.240327. Berdasarkan hasil ini dapat dilihat bahwa pertumbuhan ekonomi berpengaruh negatif terhadap pengangguran. Jika pertumbuhan ekonomi meningkat sebesar 1 persen, maka pengangguranakan menurunkan sebesar 0.240 persen.

d. Nilai slope $\beta_{3}-5.072613$ menunjukkan bahwa variabel dummy krisis ekonomi tahun 2008 berpengaruh positif terhadap pengangguran. Artinya, krisis ekonomi tahun 2008 menyebabkan pengangguran naik 5.07 persen.

\section{G. Kesimpulan}

Berdasarkan hasil analisis maka dapat ditarik beberapa kesimpulan yaitu:

1. Inflasi tidak berpengaruh terhadap pengangguran di Kota Medan, Pematangsiantar, Padangsidimpuan dan Sibolga untuk tahun 2004 sampai 2015. Hal ini dapat dilihat dari uji t, dengan $t_{\text {hitung }}-0.147921<t_{\text {tabel }}$ yang diperoleh 2.01537 .

2. Pertumbuhan ekonomi tidak berpengaruh terhadap pengangguran di Kota Medan, Pematangsiantar, Padangsidimpuan dan Sibolga untuk tahun 2004 sampai 2015. Hal ini dapat dilihat dari uji t, thitung yang diperoleh sebesar $0.369640<\mathrm{t}_{\text {tabel }}$ yang diperoleh 2.01537 . 
3. Secara simultan, inflasi dan pertumbuhan ekonomi berpengaruh terhadap pengangguran di Kota Medan, Pematangsiantar, Padangsidimpuan dan Sibolga untuk 2004 sampai 2015. Hal ini dapat dilihat dari uji F, dengan $\mathrm{F}_{\text {hitung }}$ yang diperoleh $7.101933>$ yang diperoleh $\mathrm{F}_{\text {tabel }} 2.82$.

\section{Endnotes:}

${ }^{1}$ Mohammad Rifqi Muslim, "Pengangguran Terbuka dan Determinannya" dalam Jurnal Ekonomi dan Pembangunan, Volume 15 Nomor 2, Oktober 2014, hlm. 171.

${ }^{2}$ Sonny Sumarsono,Teori dan Kebijakan PubliK Ekonomi Sumber Daya Manusia,(Yogyakarta: Graha Ilmu, 2009), hlm. 259-260.

${ }^{3}$ Boediono, Teori Pertumbuhan Ekonomi (Yogyakarta; BPFE 1992), hlm. 155.

${ }^{4}$ Rozalinda, Ekonomi Islam (Teori Aplikasinya Pada Aktifitas Ekonomi), (Jakarta: Rajawali, 2014). hlm. 307.

${ }^{5}$ Ibid., hlm. 309.

${ }^{6}$ Sadono Sukirno, Makro Ekonomi Teori Pengantar, (Jakarta: Rajawali Pres, 2010). hlm. 342.

${ }^{7}$ Rozalinda, Op. Cit., hlm. 298.

${ }^{8}$ Ibid., hlm. 359.

${ }^{9}$ Sadono Sukirno, Op. Cit., hlm.34.

${ }^{10}$ Rozalinda, Op.Cit., hlm. 310.

${ }^{11}$ M.Quraish Shihab, Tafsir Al-Misbah Pesan, Kesan dan Keserasian Al-Qur'an (Jakarta: Lentera Hati, 2002), hlm. 178.

${ }^{12}$ Nachrowi Djalal Nachrowi, Ekonometrika untuk Analisis Ekonomi dan Keuangan, (Jakarta: LPFEUI, 2006), hlm. 311.

${ }^{13}$ N.Gregory Mankiw, Teori Makro Ekonomi, (Jakarta : PT. Gelora Aksara Pratama, 2003). hlm. 154.

\section{DAFTAR PUSTAKA}

Adiwarman A Karim, Ekonomi Makro islam, Jakarta: Rajawali Pres 2012.

Budiono, Teori Pertumbuhan Ekonomi, Yogyakarta; BPFE 1992.

Junaiddin Zakaria, Pengantar Teori Ekonomi Makro, Jakarta: Gaung persada pres, 2009.

Nachrowi Djalal Nachrowi, Ekonometrika untuk Analisis Ekonomi dan Keuangan, Jakarta: Lembaga Penerbit Fakultas Ekonomi Universitas Indonesia, 2006. 
Nurul Huda, Ekonomi Makro Islam: Pendekatan Teoritis, Jakarta: Kencana, 2008.

N.Gregory Mankiw, Teori Makro Ekonomi, Jakarta: PT. Gelora Aksara Pratama, 2003.

Michael P. Todaro, dan Stephen C. Smith, Pembangunan Ekonomi Di dunia Ketiga. Jakarta: Erlangga, 2003.

Moch Doddy dan Arie fianto, Ekonomitrika esensi dan aplikasi dengan mengunakan Eviews, Jakarta: Erlangga, 2012.

Mohammad Rifqi Muslim, "Pengangguran Terbuka dan Determinannya "dalam Jurnal Ekonomidan Pembangunan, Volume 15 Nomor 2, Oktober 2014.

Pratama Raharja dan Manurung, Mandala, Pengantar Ilmu Ekonomi (Mikro Ekonomi dan Makro ekonomi), Jakarta: LPFEUI, 2008.

Setiawan dan Dwi Endah Kusrini, Ekonometrika, Yogyakarta: AndiOfset, 2010.

Rozalinda, Ekonomi Islam (Teori dan Aplikasinya pada Aktifitas Ekonomi), Edisi Pertama, Jakarta: Rajawali Pers, 2014.

Sadono Sukirno, Ekonomi Pembangunan Proses masalah, dan Dasar Kebijakan, Edisi Kedua, Jakarta: Kencana, 2006. , Makro Ekonomi Teori Pengantar, Edisi Tiga, Jakarta: Rajawali Pres, 2010.

Sonny Sumarsono, Teori dan Kebijakan Publik Ekonomi Sumber Daya Manusia, Edisi Pertama, Yogyakarta: Graha Ilmu, 2009. 